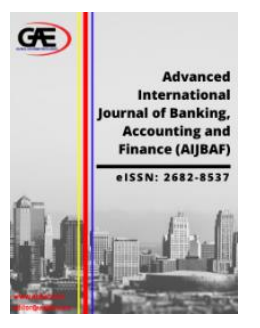

\author{
ADVANCED INTERNATIONAL JOURNAL OF \\ BANKING, ACCOUNTING AND FINANCE \\ (AIJBAF) \\ www.aijbaf.com
}

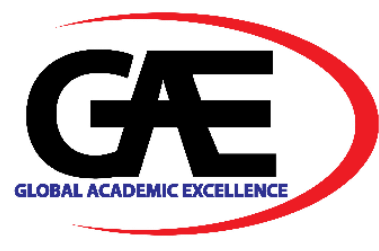

\title{
SIZE, AGE AND LEVERAGE OF NIGERIA QUOTED OIL AND GAS CORPORATIONS
}

\author{
Onipe Adabenege Yahaya ${ }^{1 *}$, Bilyaminu Tijjani ${ }^{2}$ \\ 1 Department of Accounting, Faculty of Management Sciences, Nigerian Defence Academy, Kaduna, Nigeria \\ Email: yoadabenege@nda.edu.ng \\ 2 Department of Economics, Faculty of Arts and Social Sciences, Nigerian Defence Academy, Kaduna, Nigeria \\ Email: bilyaminutijani@nda.edu.ng \\ * Corresponding Author
}

\section{Article Info:}

Article history:

Received date: 17.02 .2021

Revised date: 14.03.2021

Accepted date: 15.03 .2021

Published date: 16.03.2021

\section{To cite this document:}

Yahaya, O. A., \& Tijjani, B. (2021). Size, Age And Leverage Of Nigeria Quoted Oil And Gas Corporations. Advanced International Journal of Banking, Accounting, and Finance, 3 (6), 51-60.

DOI: $10.35631 /$ AIJBAF.36005.

This work is licensed under $\mathrm{CC}$ BY 4.0

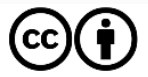

\begin{abstract}
:
Firm size and age influence firm-level leverage. The extent of such influence on the oil and gas industry is not known in Nigeria. There are very few empirical studies that interrogate the effects of firm size and listing age on leverage in Nigeria. This study examines the impacts of firm size and listing age on firm-level financial leverage of listed oil and gas companies in Nigeria. It was non-experimental research and correlational in nature. Data were extracted from annuals and accounts of 8 firms over a period of 13 years (20072019) and subjected to descriptive statistics (number of observations, mean, standard deviations, mean, minimum and maximum means) and inferential statistics (multiple regression analysis). The findings show that firm size has a negative and significant impact on firm-level financial leverage. Firm age has a positive and significant effect on firm-level leverage. In this paper, we contribute to the literature by examining the presence and direction of firm size and listing age to financial leverage user data from listed oil and gas firms in Nigeria. Our study is the first to address the adverse implications of Modeling with firm size and listing age on firm-level financial leverage.
\end{abstract}

Keywords:

Age, Leverage, Nigeria, Oil And Gas, Size

\section{Introduction}

Financial leverage (FL), otherwise also known as debt, or gearing could be an important part of organizational capital structure. Yet, very few empirical studies have examined the effect of 
Volume 3 Issue 6 (March 2021) PP. 51-60

DOI 10.35631/AIJBAF.36005

FL on firm size and age in Nigeria, particularly oil and gas sector. Most of the studies are on effect of leverage on firm financial performance or firm value (Adegboyega et al., 2019; Dada \& Ghazali, 2016; Jeleel \& Olawiyola, 2017; Kenn-Ndubuisi \& Nweke, 2019; Nelson \& Peter, 2019; Nwanna et al, 2017) or effect of firm size on firm performance (Abassi \& Malik, 2015; Kuncova et al., 2016; Lopez-Valieras et al., 2016; Oyelade, 2019; Vinasithamby, 2015) or effect of firm age on firm performance (Gunu \& Adamade, 2015; Nakano \& Nguyen, 2011; Pervan et al., 2017; Mallinguh et al., 2020).

FL is the ratio of a firm's borrowed capital to total assets or equity. It is also known as gearing and is often considered as an explanatory factor affecting financial performance or dividend policy or any factor and not as explained variable. This study is unique in that financial leverage was used as a dependent variable rather than independent variable or control variable. Financial leverage is affected by several factors. In this study, we will consider only two factors: firm size and listing age. In other words, whether big size firm or small size firms or old firms or young firms have financial leverage in their portfolios.

Larger firms have generally high leverage, profit and less deviate from standards. The opposite is true for smaller firms. This is valid because larger firms have high cash and can invest these cash resources. For example, Apple has recently started Apple TV and debit cards. Similarly, older firms have less financial leveraged because they have been around to know their ways around. GM, Apple, many other companies are classical examples.

The oil and gas industry is still Nigeria's premium when it comes to foreign direct investment. It is expected to grow at 5\% (mordorintelligence.com). Major factors driving the sector are the increasing investments in the upstream and downstream sectors; activities of the government in the sector (Nigeria's offshore exploration and production; etc. Given the world loss of interest in oil and the presence of abundant gas in Nigeria, the sector is set to be rejuvenated as soon COVID-19 is over. This study is apt and important for the obvious reasons of policy improvement, performance improvement, areas of further research and body of knowledge. The study is however limited by scope in terms of time, space and content boundary.

\section{Literature Review and Hypotheses Development}

The Modigliani and Miller (1958) developed the thesis that there is no optimum financial gearing or leverage because all information is reflected in the present market value and its future earnings. At its elementary level, the thesis suggests that it does not matter how a company finances its growth either by borrowing, by issuing share/equity or by re-vesting its profits (ploughing back). The thesis has had its impact on company finance. However, the assumption on which this was based has seriously changed and the position of experts has also changed (Fama \& Miller, 1972; Miller, 1991). This paper is based on this new theory.

Otherwise known as the theory of finance, is the main foundation on which this paper was based. The theory of finance is concerned with how well firms and individuals allocate resources over time among pressing needs. In practice, it seeks to explain how solutions to the problems encountered in allocating resources through time are facilitated through the interactions of the capital market. 
Volume 3 Issue 6 (March 2021) PP. 51-60

DOI 10.35631/AIJBAF.36005

A central and perhaps the main theme of the theory is how the capital market works. It allows firms and individuals to efficiently trade much needed funds from surplus areas. The early part of their work is concerned with no certainty, which was replaced with a more complicated real life situation of uncertainty. The theory solved the problem of resource allocation by considering the opportunities available to both firms and individuals.

Firm size and listing age are two factors that have influences on firm level leverage. Others are asset structure, growth opportunities, non-tax shied, profitability, tangibility, pecking order, asymmetric information, capital adequacy, complexity of business, dependence on external finance, liquidity and risk. For example, Do et al. (2020) found age and firm size to have positive influence on firm-level financial leverage. Forte et al. (2013) found size to be related positive to financial leverage. Age of the firm to be negative related to financial leverage.

\section{Firm Size and Firm Level Leverage}

Ezeoha (2008) investigated from an undeveloped market perspective, the nature and significance of firm size as a determinant of corporate financial leverage in Nigeria. A panel data fixed-effects regression model was used to estimate the relationship between financial leverage and firm size, while controlling also for the effects of other determinants like asset tangibility, profitability and firm age. The dataset used covers 71 quoted companies in the Nigerian Stock Exchange over a 17-year period (1990-2006). The study revealed that 91.4 per cent of the total finances of Nigerian-quoted firms were of short-term liabilities, with just 8.6 per cent constituting long-term liabilities. It found that firm size was negatively and significantly related to financial leverage. Controlling for some other determinants, the arising results confirmed an over-bearing influence of the pecking order theory in the financing patterns of Nigerian-quoted firms; by revealing that the relationship between profitability and financial leverage was also highly significant and negative; and that firm-age was positively and significantly related to financial leverage.

Vithessonthi and Tongurai (2014) found small firms with high leverage and big firms with small leverage. Marete (2015) established the relationship between firm size and financial leverage of companies listed at the Nairobi Securities Exchange. Specifically the study established the effect of firm size, profitability and sales volume on financial leverage of companies listed Nairobi Securities Exchange. Based on the trade off and pecking order theory, the study answered the research question whether firm size affects financial leverage of firms listed at Nairobi Securities Nairobi. A census survey was carried out on all the 64 listed companies between 2010 and 2014 in Nairobi Securities Exchange. Financial leverage was measured using debt/equity. The variables were tested using regression analysis and Pearson's Product Moment Correlation analysis. Descriptive statistics were computed for the listed companies and the main variables. The findings revealed that the relationship between firm size and financial leverage was statistically significant. There was a significant positive relationship between firm size and financial leverage. The study also confirmed that there was a negative significant relationship between profitability (ROA) and financial leverage. It was also established that there was a negative significant relationship sales volume and financial leverage. The study not only contributes to understanding the link between firm size and financial leverage but at the same time confirms the findings of previous studies that have found a significant link between firm size and financial leverage. 
Volume 3 Issue 6 (March 2021) PP. 51-60

DOI 10.35631/AIJBAF.36005

Hallajian and Tilehnoui (2016) provided an illustrative proof for effect of firm size on leverage; 139 firms from 13 economic sectors listed on National Stock Exchange of India were selected for this study. According to the empirical results, firm size does not have a significant effect on leverage, but it has effect for some sectors such as Energy, Chemicals and Fertilizers, Textiles, FMCG and Consumer Durables is positive and significant.

Qamar et al. (2016) explored leverage-performance relation while the moderating factor was firm size in developing countries like Pakistan. Data was collected for 304 Pakistani nonfinancial firms for the period of 2005-2013. It was found that overall leverage-performance relation was negative for all types of firms. However, such losses are more prominent for small size firms. Results also showed that the leverage-performance relation was nonlinear for medium and large size firms. However, in practice these firms are not targeting optimal level and over-leveraging that ultimately decrease their profits. So, financial managers of small size firms should avoid debt financing while for large and medium size firms need to adjust their debt ratio.

Ibhagui and Olokoyo (2018) found that leverage has negative effect on small firms rather than big firms. Salah and Elewa (2018) investigated the effect of firm's size and leverage of publicly listed firms adopting International Financial Reporting Standards. A Panel data fixed-effects regression model was employed to estimate the relationship between firm size and leverage, while controlling also for the effects of other variables as asset turnover and liquidity. The study was based on a sample of 94 firms from Malaysia over the period from 2012 to 2016. The study was applied to the industrial sector. The study concluded that firm size was positively and significantly related. This study contributes to the literature by using data from a developing country. It provides an important insight on the international debate on the effects of firm size and leverage.

Also, Hashini and Madumali (2018) investigated the effect of firm size on financial leverage. The firm size was the independent variable and financial leverage was the dependent variable. Total assets and Sales Volume used to measure size of the firm and total debt ratio used to measure financial leverage in the study. The study investigated any linkage between firm size and financial leverage and also checks whether firm size has any effect on the financial leverage. The technique of regression analysis and descriptive statistic model was used for data analysis. There were 10 listed manufacturing companies at Colombo Stock Exchange of Sri Lanka as sample over the period of 2012 to 2016 and this research used Quantitative approach. It used secondary data from annual reports. According to this study, Sales Volume was a positively correlate and significantly affect with Debt ratio in evaluating listed manufacturing companies at CSE in Sri Lanka. In addition, Total Assets had negatively relation with Debt ratio but it was insignificant level.

Chatterjee and Eyigungor (2019) found large firms have high leverage. Sundas (2019) studied the effect of firm size on financial leverage choice while controlling for determinants like profitability and performance. Fixed effect regression model was employed over an unbalanced panel data of non-financial firms of Pakistan from 2005-2014. Results reported negative relation between firm size and leverage ratios; implying less dependence of firms on debt. Profitability shows negative significant association with short term debt and total debt while performance reports insignificant relation. 
Ghozali et al. (2020) found positive influence of firm size on financial leverage. Bhat et al. (2020) found negative relationship between firm size and leverage. Baloch et al. (2020) found firm size to have negative significant effect on financial leverage. Therefore, this study predicts that:

$\mathrm{H}_{0 \mathrm{a}}$ : Firm size has no significant effect with leverage of listed oil and gas firms in Nigeria.

\section{Listing Age and Firm Level Leverage}

Ezeoha (2009) found firm age to be associated positively and significantly with financial leverage. Ikechukwu and Cyril (2017) examined the effect of listing age on corporate financial leverage of oil and gas firms in Nigeria. The study also considered the trend of the variables, the relationships among the variables, as well as their causality. This made the study a metaanalysis of the time series data. Simple regression was applied to estimate the effect of listing age on financial leverage of the selected firms. Correlation and Granger Causality Tests were applied to ascertain the relationships and causalities among the model variables. The outcome of the analysis was that firm's listing age had a significant but negative effect on financial leverage, which implies that, as oil firms advanced in age, the firms' need for external financing reduced. Causality test revealed that at a lagged period of one year, there is no causality running from financial leverage to firm age and vice versa. This implied that financial leverage was not caused by listing age of the oil and gas firms or otherwise. When the relationship between firm age and financial leverage was tested, the test revealed that financial leverage had insignificant negative relationship with firm age. The sustainability of thesis outcomes over a long period of time was also tested using the Johansen Cointegration Test which indicated cointegrating equations which implied that short run effects and relationships were very sustainable.

Memon et al. (2019) found that firm age increased as leverage decreased. Arilyn (2019) found that firm age has no influence on capital structure in Indonesia. Therefore;

$\mathrm{H}_{0 \mathrm{~b}}$ : Firm age has no significant impact on leverage.

\section{Methodology}

This is a non-experimental research which establishes statistical effects of firm size and age on firm leverage with no influence from extraneous variable. It is a correlational study and examined data for 13 years (2007-2019). The firms are 8 selected from 12 quoted oil and gas firms in Nigeria. The basis for selection was that firms with below listing standard (BLS) were dropped from the population and by implication, 4 companies were dropped from the population. Data were collected from annual reports and accounts of the remaining firms and analysed through descriptive statistics such as the number of observations, mean, standard deviations, minimum and maximum means and inferential statistics such as correlation matrix and multiple regression analysis. The model of the study is notionally represented as:

$$
\operatorname{LEV}_{i, t}=\beta o+\beta_{1} \text { FSIZ }_{i, t}+\beta_{2} \text { LAGE }_{i, t}+e_{i, t}
$$

Whereas:

LEV = Leverage defined as total debt divided by total assets (Do et al., 2020)

$\mathrm{i}=$ Firm scripts $(\mathrm{i}=8$ firms $)$ 
$\mathrm{t}=$ Time script $(\mathrm{t}=13$ years $)$

$\beta 0=$ Constant

$\beta_{1-2}=$ Coefficients

LAGE = Listing age (Shumway, 2001; Yahaya, et al., 2017)

FSIZ = Firm size, measured by the natural logarithm of total assets (Baloch et al., 2020; Ezeoha, 2008; Vithessonthi \& Tongurai, 2016)

$\varepsilon=$ Error term

\section{Results and Discussion}

The descriptive statistics are presented as follows.

Table 1: Descriptive Statistics

\begin{tabular}{lccccc}
\hline Variable & Obs & Mean & Std. Dev. & Min & Max \\
\hline LEV & 104 & .778 & .247 & .315 & 2.479 \\
LAGE & 104 & 26.75 & 11.586 & 2.00 & 48.0 \\
FSIZ & 104 & 7.717 & .529 & 5.97 & 9.030 \\
\hline
\end{tabular}

Source: Outputs from Stata 13

Descriptive statistics in from Table 1 show the number of observations, the mean, standard deviation, minimum and maximum mean values. The number of observation is 104 which are the 8 firms multiplied by 13 years. Leverage has a maximum approximately $2.5 \%$ and a minimum rate of $.315 \%$ with mean of .778 and standard deviation of .247 . The maximum listing year in the sample is 48 years and the minimum listing years is 2 with mean of 26.75 and standard deviation of 11.586. Firm size has mean of 7.717 and standard deviation of .529 with minimum and maximum mean of 5.97 and 9.03, respectively. The implication is that listing age has the highest mean, followed by firm size and finally leverage.

Table 2: Chen-Shapiro QH* Test For Normal Data

\begin{tabular}{lcccc}
\hline Variable & Obs & QH & QH* $^{*}$ & P-value \\
\hline LEV & 104 & 0.786 & 2.184 & $<0.000$ \\
LAGE & 104 & 0.992 & 0.084 & $<0.004$ \\
FSIZ & 104 & 0.989 & 0.115 & $<0.002$ \\
\hline
\end{tabular}

Source: Outputs from Stata 13

From the figures in Table 2, it is clear that LEV, LAGE and FSIZ are not normally distributed as it can be seen from their p-values which are significant, that is, less than .05. This required that the multiple regression model be a robust one.

Table 3: Results of Multicollinearity Analysis

\begin{tabular}{lcc}
\hline Variable & Variance Inflation Factor & Tolerance Level \\
\hline Fsiz & 1.09 & 0.913 \\
Lage & 1.09 & 0.914 \\
Mean VIF & 1.09 & \\
\hline
\end{tabular}

Source: Outputs from Stata 13

Table 3 shows that there no presence of multicollinearity in the data sets because the figures are less than 3.33, which is the minimum threshold number required for the test. As a rule of 
Volume 3 Issue 6 (March 2021) PP. 51-60

DOI 10.35631/AIJBAF.36005

thumb, a VIF of 1 is good for the regression and we have average VIF of 1.09, which is around 1 and good for the regression. Therefore, there is no need to drop off any of the variables in the model.

Table 4: Results of Hausman Specification Test

\begin{tabular}{lc}
\hline $\mathrm{Chi}^{2}(1)$ & 6.66 \\
\hline Prob $>\mathrm{chi}^{2}$ & 0.036 \\
\hline
\end{tabular}

Source: Outputs from Stata 13

From the results in Table 4, it is evidently clear that Fixed Effect Model is the appropriate model for the study; because the p-value is significant. Table 5 shows results based on the Fixed Effect Model (FEM).

Table 5: Results of Regression Analysis (FEM)

\begin{tabular}{lcccc}
\hline LEV & Coef. & Std. Err. & $\mathrm{t}$ & $\mathrm{P}>\mathrm{t}$ \\
\hline LAGE & .0248 & .011 & 2.35 & 0.021 \\
FSIZ & -.302 & .132 & -2.29 & 0.024 \\
_cons & 2.445 & .810 & 3.02 & 0.003 \\
F $(2,94)$ & 2.98 & & & \\
Prob $>$ F & .056 & & & \\
$\mathrm{R}^{2}$ & .0164 & & & \\
\hline
\end{tabular}

Source: Outputs from Stata 13

As indicated in Table 5, leverage has positive effect of $2.48 \%$ on every year the firms listing age increases. However, leverage suffers a negative effect of $30.2 \%$ whenever firm size is increased. The results in Table 5 indicate that both are significant; that is to say that hypothesis $0 \mathrm{a}$, which states that firm size has no significant effect on leverage, is rejected. However, it is negative which might be as result of inertia, complacency and over-reliance on past results. Similarly, hypothesis $0 \mathrm{~b}$, which states that listing age has no significant effect on leverage, is rejected. Old age comes with experience and sound judgment; thus, management is able to take the right decision on leverage and enhances profitability.

\section{Conclusions and Recommendations}

In this study, we contribute to the literature by examining the impacts of size and listing age on leverage of listed oil and gas companies in Nigeria. According to the results, age is a major positive determinant but firm size is a major negative determinant of leverage. The results contribute to the debate on the impacts of listing age and firm size on financial leverage. For highly leveraged firms, they should take advantage of their experience and reduce leverage while reducing their investments in total assets.

\section{References}

Abassi, A., \& Malik, Q. A. (2015). Firms' size moderating financial performance in growing firms: An empirical evidence from Pakistan. International Journal of Economics and Financial Issues, 5(2), 334-339.

Adegboyega, A., Jayeola, O., Olugboyega, K. S., \& Olufemi, A. T. (2019). Does leverage affect the financial performance of Nigerian firms? Journal of Economics \& Management, 37, 5-22. 
Volume 3 Issue 6 (March 2021) PP. 51-60

DOI 10.35631/AIJBAF.36005

Arilyn, E. J. (2019). The influence of firm age, tangibility, operating revenue and depreciation ratio toward capita structure in automotive and components companies listed in Indonesia Stock Exchange Period 2007-2018. Int. J. of Business, Economics and Law, 19(1), 1-4.

Baloch, Q. B., Ihsan, A., Kakakhel, S. J., \& Sethi, S. (2020). Impact of firm size, asset tangibility and retained earnings on financial leverage: Evidence from auto sector, Pakistan. Abasyn Journal of Social Sciences, 8(1), 143-155.

Bhat, D. A., Chanda, U., \& Bhat, A. K. (2020). Does firm size influence leverage? Evidence from India. Global Business Review. Doi.org/10.1177/0972150919891616.

Chatterjee, S., \& Eyigungor, B. (2019). The firm size and leverage relationship and its implications for entry and concentration in a low interest rate world. Fed. Res. Bank of Philadelphia, USA.

Dada, A. O., \& Ghazali, Z. (2016). The impact of capital structure on firm performance: Empirical evidence from Nigeria. IOSR Journal of Economics and Finance, 07(04), 2330. DOI: 10.9790/5933-0704032330.

Do, L. H., Nguyen, T. X., Le, C. V., \& Nguyen, G. L. (2020). Impacts of firms' characteristics on leverage ratio in emerging real estate market. Journal of Organizational Behavior Research, 5(1), 284-305.

Ezeoha, A. E. (2008). Firm size and corporate financial leverage choice in a developing economy: Evidence from Nigeria. The Journal of Risk Finance, 9, 351-364. Doi: 10.1108/15265940810895016.

Fama, E. F., \& Miller, M. H. (1972). The theory of finance. Holt, Rinehart \& Winston.

Forte, D., Barros, L. A., \& Nakamura, W. T. (2013). Determinants of capital structure of small and medium size Brazilian enterprises. Brazilian Administration Review 10(3), July/Sept. https://doi.org//10.1590/51807-709222013000300007.

Gunu, U., \& Adamade, S. S. (2015). The relationship between firm age and financial performance in Nigeria: A panel analysis. Journal of Sustainable Development in Africa, 17(3), 128-141.

Ghozali, I., Handriani, E., \& Hersungodo (2020). Leverage determinants of manufacturing firm: Evidence from Indonesia. International Journal of Scientific and Technology Research, 9(4), 2734-2744. www. ijstr.org.

Hallajian, E., \& Tilehnoui, M. H. (2016). Impact of firm size on leverage: An empirical study of companies listed on NSE of India. International Journal of Scientific Research, 5(5):99-101.

Hashini, A. M. C., \& Madumali, P. A. (2018). Effect of firm size on financial leverage. Global Scientific Journal, 6(7), 70-76.

Ibhagui, O. W., \& Olokoyo, F. O. (2018). Leverage and firm performance: New evidence on the role of firm size. The North American Journal of Economics and Finance, 45, 5782. https://Doi.org/10.1016/j.najef.2018.02.002.

Ikechukwu, I. O., \& Cyril, U. M. (2017). Effect of listing age on corporate financial leverage of oil and gas firms in Nigeria. International Journal of Economics, Finance and Management Sciences, 5(2), 92-97. Doi: 10.11648/j.ijefm.20170502.12.

Jeleel, A., \& Olawiyola, B. (2017). Effect of leverage on firm performance in Nigeria: A case of listed chemicals and paints firms in Nigeria. Global Journal of Management and Business Research: D Accounting and Auditing, 17(2)(1), 14-24. 
Volume 3 Issue 6 (March 2021) PP. 51-60 DOI 10.35631/AIJBAF.36005

Kenn-Ndubuisi, J. I., \& Nweke, C. J. (2019). Financial leverage and firm financial performance in Nigeria: A panel data analysis approach. Global Journal of Management and Business Research: C Finance, 19(4)(1), 12-19.

Kuncova, M., Veronika, H., \& Fiala, R. (2016). Firm size as a determinant of firm performance: The case of swine raising. Agris On-line Papers in Economics and Informatics, 8(3), 77-89. DOI: 10.7160/aol.2016.080308.

Lopez-Valieras, E., Gomez-Conde, J., \& Fernandez-Rodriguez, T. (2016). Firm size and financial performance: Intermediate effects of indebtedness. Agribusiness: An International Journal, 34(4), 454-465. DOI: https://doi.org/10.1002/agr.21458.

Mallinguh, E., Wasike, C., \& Zoltan, Z. (2020). The business sector, firm age, and performance: The mediating role of foreign ownership and financial leverage. International Journal of Financial Studies, 8(79), 1-16.

Marete, D. (2015). The relationship between firm size and financial leverage of firms listed at Nairobi Securities Exchange. Master of Business Administration, School of Business, University of Nairobi.

Memon, Z. A., Chen, Y., \& Samo, A. A. (2019). Corporate governance, firm age and leverage: Empirical evidence from China. Research Journal of Finance and Accounting, 10(2), 19-31. Doi. 10.7176/RJFA/10-2-03.

Miller, M. H. (1991). Financial innovations and market volatility. Blackwell Publishing.

Modigliani, F., \& Miller, M. (1958). The cost of capital, corporation finance and the theory of investment. The American Economic Review, 48(3), 261-297.

mordorintelligence.com (2020). Nigeria oil and gas market: Growth, trends and forecasts (2020-2025).

Nakano, M., \& Nguyen, P. (2011). Do older boards affect firm performance? An empirical analysis based on Japanese firms. Available at SSRN: https://ssrn.com/abstract=1879250.

Nelson, J., \& Peter, E. A. (2019). An empirical analysis of effect of capital structure on firm performance: Evidence from microfinance banks in Nigeria. European Journal of Accounting, Auditing and Finance Research, 7(9), 30-44.

Nwanna, I., Onyenwe, N. I., \& Ivie, G. (2017). Effect of financial leverage on firm's performance: A study of Nigerian banks (2006 -2015). Banking Regulation in Nigeria. DOI: $10.24327 /$ ijrsr.2017.0807.0530.

Oyelade, A. (2019). The impact of firm size on firms' performance in Nigeria: A comparative study of selected firms in the building industry in Nigeria. Determinants of Export Diversification in Nigeria: Any Special Role for Foreign Direct Investment?

Pervan, M., Pervan, I., \& Curak, M. (2017). The influence of age on firm performance: Evidence from the Croatian food industry. Journal of Eastern Europe Research in Business \& Economics, 2017, 1-10. DOI: 10.5171/2017.618681.

Qamar, M. A. J., Farooq, U., \& Akhtar, W. (2016). Firm size as moderator to leverageperformance relation: An emerging market review. Journal of Poverty, Investment and Development, 23, 55-62.

Salah, W., \& Elewa, M. (2018). The effect of firm's size on leverage: A panel data approach. Journal of Applied Economic Sciences, 13(6), 1723-1732.

Sundas, S. (2019). Firm size and financial-leverage choice: Evidence from an emerging economy. International Journal of Commerce and Finance, 5(1), 25-33. 
Volume 3 Issue 6 (March 2021) PP. 51-60 DOI 10.35631/AIJBAF.36005

Vinasithamby, S. (2015). Does firm size influence on firm's Profitability? Evidence from listed firms of Sri Lankan Hotels and Travels sector. Research Journal of Finance and Accounting, 6(6), 201-207.

Vithessonthi, C., \& Tongurai, J. (2014). The effect of firm size on the leverage-performance relationship during the financial crisis of 2007-2009. Department of Accountancy and Finance, School of Business, University of Otago, Dunedin 9054, New Zealand.

Yahaya, O. A., Tanko, M., \& Muhammad L. M. (2017). Effects of corporate characteristics on earnings quality of listed deposit money banks in Nigeria. KASU Journal of Mgt. Sciences, 8(1), 47-64. 